\title{
A prospective study of sublingual misoprostol following mifepristone for second trimester termination of pregnancy
}

\author{
Ruchi Gupta, Krishna Priya Banerjee, Reena Pant \\ Correspondence: Dr Ruchi Gupta, Senior Resident, Department of Obstetrics and \\ Gynecology , S.M.S. Medical college , Jaipur , Rajasthan, India; Email - \\ ruchiguptamgm@gmail.com
}

Distributed under Attribution-NonCommercial - Share Alike 4.0 International (CC BY-NC-SA 4.0)

\begin{abstract}
Objectives: This prospective study was done to evaluate the effectiveness, acceptability and side effects of sublingual misoprostol for second trimester termination of pregnancy. Materials and Methods: This hospital based prospective study was conducted on 110 women for second trimester abortion from 12-20 weeks during 2012-13.The women enrolled received $200 \mathrm{mg}$ mifepristone, than sublingual misoprostol 400 microgram 3 hourly for 5 doses after 48 hours. The results were expressed in terms of induction abortion interval, dosage, success rate, acceptability and side effects. Results: The mean induction -abortion interval was shorter in multigravida i.e. $3.84 \pm 0.866$ hours as compare to primigravida i.e. $4.54 \pm 1.79$ hours. Also the mean inductionabortion interval was shorter in women with period of gestation 12-16 weeks i.e. $3.98 \pm 1.055$ hours as compare with gestational age 17-20 weeks with induction-abortion abortion interval of $4.05 \pm 1.592$ hours ( $\mathrm{p}=0.08$, NS). The mean dose of misoprostol was lesser in multigravida i.e. $670.0 \pm 189.8 \mu \mathrm{g}$ as compare to primigravida i.e. $739.4 \pm 226.3 \mu \mathrm{g}(\mathrm{p}=0.2, \mathrm{NS})$. The mean dose of misoprostol required was same irrespective of gestational age i.e. $693.3 \pm 178.9 \mu \mathrm{g}$ for gestational age 12-16 weeks and $676.9 \pm 244.2 \mu \mathrm{g}$ for gestational age 17-20 weeks $(\mathrm{p}=0.07$, NS). Hundred $(100 \%)$ successful abortion rate was achieved with only $0.91 \%$ women required evacuation. The acceptability was $52.73 \%$. The side effect observed was pain abdomen (26.4\%), nausea/vomiting (34.5\%), headache (14.5\%), diarrhoea (12.7\%) and fever (12.7\%). Conclusion: From present study we conclude that sublingual misoprostol following mifepristone is highly efficacious method of second trimester abortion.
\end{abstract}

Keywords: Sublingual misoprostol, second trimester abortion.

Mifepristone is noretindrone derivative with along with cervical softening and dilatation causing antiprogestational effect. It binds to the progesterone receptors in endometrium and causes necrosis and detachment of products of conception. It also causes cervical ripening and mild uterine contractions. ${ }^{1}$ Misoprostol is synthetic prostaglandin $E_{1}$ analogue, which binds to myometrial cells causing myometrial contraction expulsion of product of conception. ${ }^{1}$ Due to these properties both mifepristone and misoprostol are recommended drugs for mid-trimester abortion. Many studies evaluated different roots of misoprostol such as oral, vaginal, buccal and sublingual. ${ }^{2}$ Buccal mucosa being highly vascular leads to effective absorption of

Received: $28^{\text {th }}$ January 2019. Accepted: $11^{\text {th }}$ March 2019.

Gupta R, Banerjee KP, Pant R. A prospective study of sublingual misoprostol following mifepristone for second trimester termination of pregnancy. The New Indian Journal of OBGYN. 2019; 6(1): 20-3 
The New Indian Journal of OBGYN. 2019 (July-December); 6(1)

misoprostol via sublingual route and also bypass the liver. The peak concentration was achieved in shortest time via sublingual route as compare to oral and vaginal route. ${ }^{3}$ In India termination of pregnancy is legal upto 20 weeks under specified conditions via medical and surgical routes. ${ }^{4}$ WHO recommends mifepristone and misoprostol as the most efficacious method of second trimester termination of pregnancy. ${ }^{5} \mathrm{We}$ had explored the use of sublingual misoprostol for second trimester abortion.

\section{Materials and Methods}

This prospective study was conducted on 110 women presenting to the Department of Obstetrics and Gynecology, Zenana Hospital, S.M.S.Medical college, Jaipur for second trimester termination of pregnancy from 12-20 weeks during 2012-13. The sample size was calculated at $80 \%$ study power and alpha error of 0.05 assuming standard deviation for duration of induction to abortion interval of 5 hours and minimum difference to be detected of 2 hours. Thus sample size comes out to be 100 which were enhanced to 110 assuming $10 \%$ drop out rates. After clearance from ethical committee and satisfying the inclusion criteria women were given medication for medical abortion with mifepristone and sublingual misoprostol after written and informed consent. Women received mifepristone $200 \mathrm{mg}$ followed by sublingual misoprostol $400 \mu \mathrm{g} 3$ hourly for 5 doses. Induction abortion interval was defined as time interval between first dose of misoprostol and expulsion of fetus. Abortion was effective if products expelled within 24 hours without need of any other medication.

The data was analysed using Microsoft excel, SPSS 20 and primer. Mean, standard deviation and proportion were used to summarize study variable. Paired T test was used to compare data. Ninety five percent $(95 \%)$ confidence interval for difference of mean was used. A p-value of $<0.05$ was considered significant statistically.

\section{Results}

Table 1 representing demographic characteristics of population studied suggested that majority of women belonged to $18-24$ year age group (48.18\%), residing in urban locality (67.27\%), mostly Hindu (84.55\%), of middle socioeconomic Kuppuswamy class (53.64\%), literate $(66.36 \%)$, mostly multigravidas (77\%) with $17-20$ weeks gestational age (59.09\%). Table 2 shows that the mean induction abortion interval. In multigravida $\left(\geq \mathrm{G}_{2}\right)$
Table 1: Demographic characteristic of study population

\begin{tabular}{ll}
\hline Characteristics & $\begin{array}{l}\text { No. of women (\%) } \\
\text { (N=110) }\end{array}$ \\
\hline Age group ( in years) & \\
\hline $18-24$ & $53(48.18 \%)$ \\
$25-29$ & $40(36.36 \%)$ \\
$30-34$ & $15(13.64 \%)$ \\
$\geq 35$ & $2(1.82 \%)$ \\
\hline Residence & \\
\hline Urban & $74(67.27 \%)$ \\
Rural & $36(32.73 \%)$ \\
\hline Religion & \\
\hline Hindu & $93(84.55 \%)$ \\
Muslim & $17(15.45 \%)$ \\
\hline Socio-economic status & \\
\hline Upper & $28(25.45 \%)$ \\
Middle & $59(53.64 \%)$ \\
Lower & $23(20.91 \%)$ \\
\hline Literacy & \\
\hline Literate & $73(66.36 \%)$ \\
Illiterate & $37(33.64 \%)$ \\
\hline Gestational age ( in weeks) & \\
\hline $12-16$ & $45(40.91 \%)$ \\
$17-20$ & $65(59.09 \%)$ \\
\hline Gravidity & \\
\hline G1 & $33(30 \%)$ \\
$\geq$ G2 & $77(70 \%)$ \\
\hline a $3.84+0.866$ hr and $)$
\end{tabular}

was $3.84 \pm 0.866 \mathrm{hrs}$ and $4.54 \pm 1.797 \mathrm{hrs}$ in primigravida i.e duration of abortion in multigravida was shorter than

Table 2: Distribution of cases according to mean induction - abortion interval and gravidity

\begin{tabular}{lll}
\hline Gravidity & $\begin{array}{l}\text { No. of women } \\
\text { (N=110) }\end{array}$ & $\begin{array}{l}\text { Induction abortion } \\
\text { interval (hours) }\end{array}$ \\
\hline G1 & 33 & $4.54 \pm 1.797$ \\
$\geq \mathrm{G} 2$ & 77 & $3.84 \pm 0.866$ \\
\hline
\end{tabular}

primigravida. Table 3 shows that the mean induction abortion interval for women with gestational age 12-16 weeks was $3.98 \pm 1.055$ hours and for gestational age 1720 weeks was $4.05 \pm 1.592$ hours i.e. smaller the gestational age shorter is the induction abortion interval.

Table 3: The mean induction abortion interval

\begin{tabular}{llll}
\hline $\begin{array}{l}\text { Gestational } \\
\text { age }(\text { in } \\
\text { weeks) }\end{array}$ & $\begin{array}{l}\text { No. of } \\
\text { women } \\
(\mathbf{N}=110)\end{array}$ & $\begin{array}{l}\text { Induction- } \\
\text { abortion interval } \\
\text { (in hours) }\end{array}$ & $\begin{array}{l}\mathbf{P} \\
\text { value }\end{array}$ \\
\hline $12-16$ & 45 & $3.98 \pm 1.055$ & 0.08 \\
$17-20$ & 65 & $4.05 \pm 1.592$ & \\
\hline
\end{tabular}

But the difference was not statistically significant $(\mathrm{p}=$ 0.08 , NS). Table 4 shows that the mean dose of misoprostol required in multigravida $\left(\geq \mathrm{G}_{2}\right)$ was $670 \pm$ 
Table 4: Distribution of cases according to mean dose of misoprostol, gravidity and gestational age

\begin{tabular}{llll}
\hline Variables & $\begin{array}{l}\text { No of } \\
\text { women } \\
(\mathbf{n = 1 1 0})\end{array}$ & $\begin{array}{l}\text { Mean dose of } \\
\text { misoprostol } \\
(\boldsymbol{\mu g})\end{array}$ & $\begin{array}{l}\mathbf{P} \\
\text { value }\end{array}$ \\
\hline Gravidity & & & \\
$\mathrm{G} 1$ & 33 & $739.4 \pm 226.3$ & 0.2 \\
$\geq \mathrm{G} 2$ & 77 & $670 \pm 189.8$ & \\
\hline Gestational age & & & \\
12-16 wks & 45 & $693.3 \pm 178.9$ & 0.07 \\
17-20 wks & 65 & $676.9 \pm 244.2$ & \\
\hline
\end{tabular}

$189.8 \mu \mathrm{gm}$ and in primigravida was $739.4 \pm 226.3 \mu \mathrm{gm}$.

Though lesser dosage of misoprostol is required in multigravida the difference was not statistically significant $(p=0.2, N S)$. However, the dosage of

Table 5: Distribution of cases according to success rate, need for evacuation, acceptability and side effects

\begin{tabular}{lll}
\hline Variables & $\begin{array}{l}\text { No. of women } \\
(\mathbf{n = 1 1 0})\end{array}$ & $\mathbf{( \% )}$ \\
\hline Successful rate & \\
\hline Successful abortion & $110(100 \%)$ \\
Failure & 0 \\
\hline Need for evacuation & \\
\hline Required & $1(0.91 \%)$ \\
Not required & $109(99.09 \%)$ \\
\hline Acceptability & \\
\hline Fairly acceptable & $58(52.73 \%)$ \\
Difficult to tolerate & $52(47.27 \%)$ \\
\hline Side-effects & \\
\hline Pain & $29(26.40 \%)$ \\
Nausea/vomiting & $38(34.50 \%)$ \\
Headache & $16(14.50 \%)$ \\
Diarrhoea & $14(12.70 \%)$ \\
Fever & $14(12.70 \%)$ \\
\hline misoprostol was same irrespective of gestational age
\end{tabular}

misoprostol was same irrespective of gestational age $(\mathrm{p}=0.07, \mathrm{NS})$. Table 5 shows $100 \%$ success rate via above regime, only $0.91 \%$ women require evacuation. The sublingual route was fairly acceptable by $52.73 \%$ women; however $47.27 \%$ does not like the route of administration. The side effect reported was pain $(26.40 \%)$, nausea/vomiting $(34.50 \%)$, headache $(14.50 \%)$, diarrhoea $(12.70 \%)$ and fever $(12.70 \%)$.

\section{Discussion}

Current study recruited 110 women, majority of which belonged to 18-29 years age group with mean age of $24.85 \pm 3.83$ years corresponding to the period of maximum fertility. The results were similar to study done by Tang Os et al $(2005)^{3}$, and Devendra Kushwah et al $(2011)^{6}$. They reported mean age of 26.5 years and 26.40 years respectively.
In our study maximum number of women belonged to urban population constituting $67.27 \%$ because our study was conducted in a Medical college hospital which caters the need of urban population. The maximum women in our study were Hindus constituting $84.55 \%$. This preponderance was obvious because of similar sort of distribution in general population. According to recent census in India $82.35 \%$ population were Hindus.

According to socioeconomic status, maximum numbers of women (53.64\%) are of middle socioeconomic class mostly because of lesser awareness regarding contraceptive methods. Majority of women in our study were literate $(66.36 \%)$ because most of women belonged to urban area.

The majority of women in our study were in 17-20 week gestation group constituting $59.09 \%$. Overall mean gestational age was $17.24 \pm 2.434$ weeks. The results were comparable to study done by Tang Os et al (2005) ${ }^{3}$, Tripti Nagaria et al (2011) ${ }^{7}$, and Kranti K Kulkarni et al $(2013)^{8}$. They reported mean gestational age of $15.3 \pm 1.7$ weeks, $16.04 \pm 2.57$ weeks and 16 weeks respectively. ${ }^{3,7,8}$

The majority of women in our study were multigravidas with mean gravidity of $2.06 \pm 0.186$. The results were comparable to study done by Tripti Nagaria et al (2012) where the mean gravidity of cases was $3.62 \pm$ $1.55^{7}$

The overall mean induction abortion interval was 4.02 \pm 1.39 hours. The results of our study were comparable to study done by Tang Os et al (2005) ${ }^{3}$, they reported the mean induction abortion interval in sublingual group was 5.5 hours. The results were also consonant with the study done by Devendra Kushwaha et al (2011) ${ }^{6}$ who found the mean \pm SD induction to evacuation interval in sublingual group was $5.6 \pm 4.54$ hours.

The mean induction-abortion interval in multigravida was $3.84 \pm 0.866$ hours and in primigravida was $4.54 \pm$ 1.797 hours. The similar observations were made by Tang Os et al $(2005)^{3}$ who found the mean induction abortion interval was greater in nulliparous women as compare to multiparous women. The mean induction abortion interval for gestational age 12-16 weeks was $3.98 \pm 1.055$ hours and for gestational age 17-20 weeks was $4.05 \pm 1.592$ hours. The induction abortion interval was shortened at lesser gestational age but the difference was not statistically significant ( $\mathrm{p}=0.08, \mathrm{NS})$. 
The overall mean dose of misoprostol was $680 \pm$ $220.4 \mu \mathrm{g}$. The results were similar to the study done by Nagaria et al (2000) ${ }^{9}$ and Caliskan et al (2005) ${ }^{10}$. They reported the mean dose of misoprostol in sublingual group was $600 \mu \mathrm{g}$ and $543 \pm 422 \mu \mathrm{g}$ respectively ${ }^{9,10}$. The mean dose of misoprostol in multigravida was $670.3 \pm 189.8 \mu \mathrm{g}$ and $739.4 \pm 226.3 \mu \mathrm{g}$. Though the dose of misoprostol required to achieve successful abortion was lower in multigravida as compare to primigravida but the difference was not statistically significant $(\mathrm{p}=0.2$, NS). The mean dose of misoprostol required was same irrespective of gestational age 12-20 weeks.

In our study $100 \%$ success rate was observed which was comparable to study done Devendra Kushwaha et al (2011) ${ }^{6}$ who reported success rate of $92 \%$ in sublingual group. The results were also consonant with study done by Tripti Nagaria et al (2012) ${ }^{7}$ with success rate of $100 \%$ in sublingual group. In our study only $0.91 \%$ women required surgical evacuation, whereas in other study done by Tang Os et al $(2005)^{3}$, evacuation was required in $17.2 \%$ cases of sublingual misoprostol.

In our study sublingual misoprostol was fairly acceptable among $52.73 \%$ women which were similar to study done by Shah et al $(2010)^{11}$ who reported $60 \%$ acceptability among sublingual group.

The most common side effect in our study was nausea /vomiting reported by $34.50 \%$ of women followed by pain $(26.40 \%)$ and headache $(14.50 \%)$.The results were similar to other studies reporting similar side effects ${ }^{3,6}$.

\section{Conclusion}

Thus we conclude that mifepristone followed by sublingual misoprostol is highly efficacious method for second trimester abortion.

\section{Conflict of interest: None. Disclaimer: Nil.}

\section{References}

1.Ministry of Health and Family Welfare. Comprehensive Abortion care: Training and Service delivery guidelines. New Delhi: Government of India; 2010.
2.Lin M, Li YT, Chen FM, Wu SF, Tsai CW, Chen TH, et al. Mifepristone and misoprostol for early medical abortion.

Taiwan J Obstet Gynecol. 2006; 45: 321-4.

3.Tang OS, Chan CC, Kan AS, Ho PC. A prospective randomized comparison of sublingual and oral misoprostol when combined with mifepristone for medical abortion at 12-20 weeks. Hum Reprod. 2005; 20(11): 3062-6.

4.Ministry of Health and Family Welfare. Medical Termination of pregnancy, regulation 2003. New Delhi: Department of family planning; 2003.

5.Trainer manual of comprehensive abortion care, 2009. Method of second trimester termination, page 233.

6.Kushwaha DS, Kushwah B, Salman MT, Verma VK. Acceptability and safety profile of oral and sublingual misoprostol for uterine evacuation following early fetal demise. Indian J Pharmacol. 2011; 43(3): 303-10.

7.Nagaria T, Sirmor N. Misoprostol Vs mifepristone and misoprostol in second trimester termination of pregnancy. The journal of Obstet and Gynecol of India. 2011; 61(6): 659-62.

8.Kulkarni KK. Preinduction with mifepristone for second trimester termination of pregnancy. The Journal of Obstet and Gynecol of India. 2014; 64(2): $102-4$.

9.Ngai SW, Tang OS, Ho PC. Randomized comparison of vaginal and oral misoprostol when combined with mfepristone in termination of second trimester of pregnancy. Hum Reprod. 2000; 15(10): 2205-8.

10.Caliskan E, Dilbaz S, Doger E, Ozeran S, Ozeren S, Dilbaz B. Randomized comparison of 3 misoprostol protocols for abortion induction at 13-20 weeks of gestation. J Reprod Med. 2005; 50(3):173-80.

11. Shah N, Azam SI, Khan NH. Sublingual versus vaginal misoprostol in the management of missed miscarriage. J Pak Med Assoc. 2010; 60(2):113-6.

Ruchi Gupta ${ }^{1}$, Krishna Priya Banerjee ${ }^{2}$, Reena Pant ${ }^{3}$

${ }^{1}$ Senior Resident; ${ }^{2}$ Professor; ${ }^{3}$ Associate Professor, Department of Obstetrics and Gynecology, S.M.S. Medical college , Jaipur , Rajasthan, India 